\title{
The Mapping of Sustainability Index in Small and Medium Enterprises: A Case Study in Lampung Indonesia
}

\author{
Lintang Harwina Madyaratry *, Hartrisari Hardjomidjojo, Elisa Anggraeni \\ Teknik Industri Pertanian, Fakultas Teknologi Pertanian Institut Pertanian Bogor, Indonesia \\ Jl. Raya Dramaga, Babakan, Bogor, West Java 16680, Indonesia \\ *Corresponding author: lintangharwina@gmail.com
}

\section{ARTICLE INFO}

Article history

Received December 12, 2019

Revised February 16, 2020

Accepted February 26, 2020

Available Online February 28, 2020

Keywords

Sustainability index

Small and medium enterprises

Performance Sustainability

SME condition mapping

\section{ABSTRACT}

Small-medium enterprises (SMEs) generally have constraints on their performance efficiency and productivity. It affects the ability of SMEs to compete in the global market. Therefore, the mapping of SME conditions needs to be analyzed. This study aims to map the SME conditions and find out SME's sustainability index. This study uses a multidimensional scaling method through ecological, social, economic, technological, and institutional dimensions. A case study was carried out at Banana Chips SMEs in Lampung Province. These SMEs are the mainstays of Lampung Province. The results show that the SME condition was divided into three categories: poor, good, and very good. The status of the sustainability of SMEs in each dimension was divided into two groups: the poor category for the technology dimension and the good category both for the ecological, social, economic, and institutional dimensions. The results of the mapping of SME's sustainability index produced several improvement strategies for SMEs.

This is an open-access article under the CC-BY-SA license.

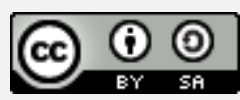

\section{Introduction}

Small Medium Enterprises (SMEs) is a business that needs to get the most attention from the government. It is since SMEs have a significant role in the Indonesian economy. According to Tambunan [1], the central function of SMEs in the Indonesian economy is as a job provider. More than $90 \%$ of their employees are women and young people. Therefore, SMEs may become the source of both primary and secondary incomes for Indonesians. Following the objectives of Law No. 20 of 2008 [2], SMEs need to obtain the opportunity, support, protection, and development as a people's business. These are expected to help SMEs grow and improve their competitiveness.

One of the popular SMEs in Indonesia is banana chips SME. These SMEs, however, have several significant constraints and obstacles, such as efficiency and productivity performance [3]. It may affect the ability of SMEs to compete in the global market. Research on SMEs has been carried out to implement innovative strategies to improve SMEs' competitiveness [4]. Management capabilities such as technical abilities, access to information, and managerial abilities as determinants of the success of the banana chips 
SMEs [5]. In the product life cycle of banana chips, the products have decreased due to the lack of influence of business infrastructure supports and environmental risks [6].

Performance improvement of the banana Chips SMEs can be realized using the sustainability index [7]. A sustainability index is a tool that can determine the sustainability status of a business. Some techniques have been carried out to assess the sustainability in the fisheries sectors [8] [9] [10]. In addition, sustainability index has been developed for measurements in sugar industry [11], rice availability [12], environmental management [13], livestock waste treatment [14], cocoa plantations [15], island sustainability index in Indonesia [16], and oil palm [17] [18].

Although many studies on the sustainability index have been carried out in various fields, very little attention has been given to the SME sector. This study aims to map the sustainability index at the banana chips SMEs in Indonesia. This study employs a Multidimensional Scaling (MDS) method with the RAPFISH (Rapid Appraisal for Fisheries) approach. The MDS method is chosen as it has been proven to produce a stable solution [19]. This study uses five dimensions: ecological, social, economic, technological, and institutional dimensions [12]. This study is expected to generate significant insights into mapping the sustainability index of the banana chips SMEs in Indonesia. Therefore, this study provides a significant contribution to research on the sustainability index in SMEs. This paper consists of four sections. Section 1 discusses the introduction, literature review, and research objectives. Section 2 explains the dimensions and attributes, data collection, and data analysis. Section 3 presents the results of the sustainability index assessment and the effects of the attributes on the sustainability index. The last section discusses the conclusion and suggestion for further research.

\section{Methods}

This section comprises dimensions of attributes, data collection, and data analysis procedure. The stages are explained as follows.

\subsection{Dimensions and Attributes}

The data collection began with a literature study to determine the study's dimensions, attributes, and indicators. The dimensions were ecological, social, economic, technological, and institutional dimensions. The determination of attributes and indicators was by each dimension. According to Hartono et al. [20], the ecological dimension is the dimension that reflects the good and bad quality of the environment and resources. The social dimension is the dimension that reflects the human social system. The economic dimension reflects an activity obtaining financial results. The technological dimension reflects the use of resources in using technology. The institutional dimension refers to the rules of an economic activity that can guarantee and support the activity. Twenty-five attributes were used to assess the sustainability index of the banana chips SMEs. The dimensions and attributes were reviewed by experts to ensure the suitability of aspects of the sustainable index. These are presented in Table 1 and Table 2.

\subsection{Data Collection}

This study was conducted at twelve banana chip SMEs in the province of Lampung, Indonesia. It made use of twenty-five attributes that corresponded to the condition of the banana chips SMEs. Furthermore, the dimensions and attributes were reviewed by some experts. The experts included academics, the head of the banana chips SME center, the officer of the Ministry of Cooperatives and SMEs of Lampung Province, the officer of the 
Cooperatives and SMEs Office of Bandar Lampung, and the officer of the Ministry of Trade of Lampung Province.

Table 1. Attributes and indicators of banana chips SME

\begin{tabular}{|c|c|c|c|}
\hline Dimension & Attribute & Reference & Scale Indicator \\
\hline \multirow[t]{21}{*}{ Ecology } & \multirow[t]{4}{*}{ Total workforce } & \multirow[t]{4}{*}{ Ardiana dan Brahmayanti [21] } & $0:$ None \\
\hline & & & 1: 1-5 People \\
\hline & & & 2: 6-10 People \\
\hline & & & 3: > 10 People \\
\hline & \multirow[t]{3}{*}{ Workforce experience } & \multirow[t]{3}{*}{ Zahro dan Suyadi [22] } & 0: No experience \\
\hline & & & $\begin{array}{l}\text { 1: Less than one year of } \\
\text { experience }\end{array}$ \\
\hline & & & $\begin{array}{l}\text { 2: More than one year of } \\
\text { experience }\end{array}$ \\
\hline & \multirow[t]{3}{*}{ Special Training } & \multirow[t]{3}{*}{ Hidayati et al. [23] } & $0:$ None \\
\hline & & & 1: $1-3$ times per year \\
\hline & & & $\begin{array}{l}\text { 2: More than three times per } \\
\text { year }\end{array}$ \\
\hline & \multirow{3}{*}{$\begin{array}{l}\text { Availability of raw } \\
\text { materials }\end{array}$} & \multirow[t]{3}{*}{ Wuryandari dan Meilani [24] } & 0: Hard to obtain \\
\hline & & & 1: Easy to obtain \\
\hline & & & 2: Very easy to obtain \\
\hline & \multirow{3}{*}{$\begin{array}{l}\text { Sustainability of raw } \\
\text { material availability }\end{array}$} & \multirow[t]{3}{*}{ Wuryandari dan Meilani [24] } & 0: Weak \\
\hline & & & 1: Moderate \\
\hline & & & 2: Strong \\
\hline & \multirow[t]{3}{*}{ Generated waste } & \multirow{3}{*}{$\begin{array}{l}\text { Cahyana et al. [25]; Erviana et } \\
\text { al. [26] }\end{array}$} & 0: Available (More) \\
\hline & & & 1: Available (Litle) \\
\hline & & & 2: None \\
\hline & \multirow[t]{2}{*}{ Waste Management } & \multirow{2}{*}{$\begin{array}{l}\text { Cahyana et al. [25]; Erviana et } \\
\text { al. [26] }\end{array}$} & $0:$ None \\
\hline & & & 1: Available \\
\hline \multirow[t]{17}{*}{ Social } & \multirow[t]{3}{*}{ Source of suppliers } & \multirow[t]{3}{*}{ Rostamzadeh dan Sofian [27] } & 0: 1 Supplier \\
\hline & & & 1: 3 Suppliers \\
\hline & & & 2: > 3 Suppliers \\
\hline & \multirow[t]{3}{*}{ Number of resellers } & \multirow[t]{3}{*}{ Rostamzadeh dan Sofian, [27] } & 0: None \\
\hline & & & 1: $<10$ Resellers \\
\hline & & & 2: $>10$ Resellers \\
\hline & \multirow{3}{*}{$\begin{array}{l}\text { Relationship } \\
\text { suppliers }\end{array}$} & \multirow{3}{*}{$\begin{array}{l}\text { Subroto et al. [28]; Anam dan } \\
\text { Setyawan [29] }\end{array}$} & 0: No relationship \\
\hline & & & 1: Weak relationship \\
\hline & & & 2: Good relationship \\
\hline & Relationship & Subroto et al. [28]; Anam dan & 0: No relationship \\
\hline & resellers & Setyawan [29] & 1: Weak relationship \\
\hline & & & 2: Good relationship \\
\hline & Relationship & Subroto et al. [28]; Anam dan & 0: No relationship \\
\hline & other SMEs & Setyawan [29] & 1: Weak relationship \\
\hline & & & 2: Good relationship \\
\hline & Relationship with the & Subroto et al. [28]; Anam dan & $0:$ No relationship \\
\hline & community & Setyawan [29] & 1: Good relationship \\
\hline Economy & Marketing area & Nuseto [30] & 0: Local \\
\hline & & & 1: Inter-island \\
\hline & & & 2: Export \\
\hline & Price & Rostamzadeh dan Sofian, [27] & $0:>$ IDR 40,000 \\
\hline & & & 1: IDR 40,000 \\
\hline & & & $2:<$ IDR 40,000 \\
\hline & Demand & Rostamzadeh dan Sofian, [27]; & 0: Low \\
\hline & & Nuseto [30] & 1: Moderate \\
\hline & & & 2: High \\
\hline & Profit allocation for & Law No. 20/2008 [2] & 0: Not available \\
\hline & investment & & 1: Available \\
\hline
\end{tabular}


Table 2. Attributes and indicators of banana chips SME (continue)

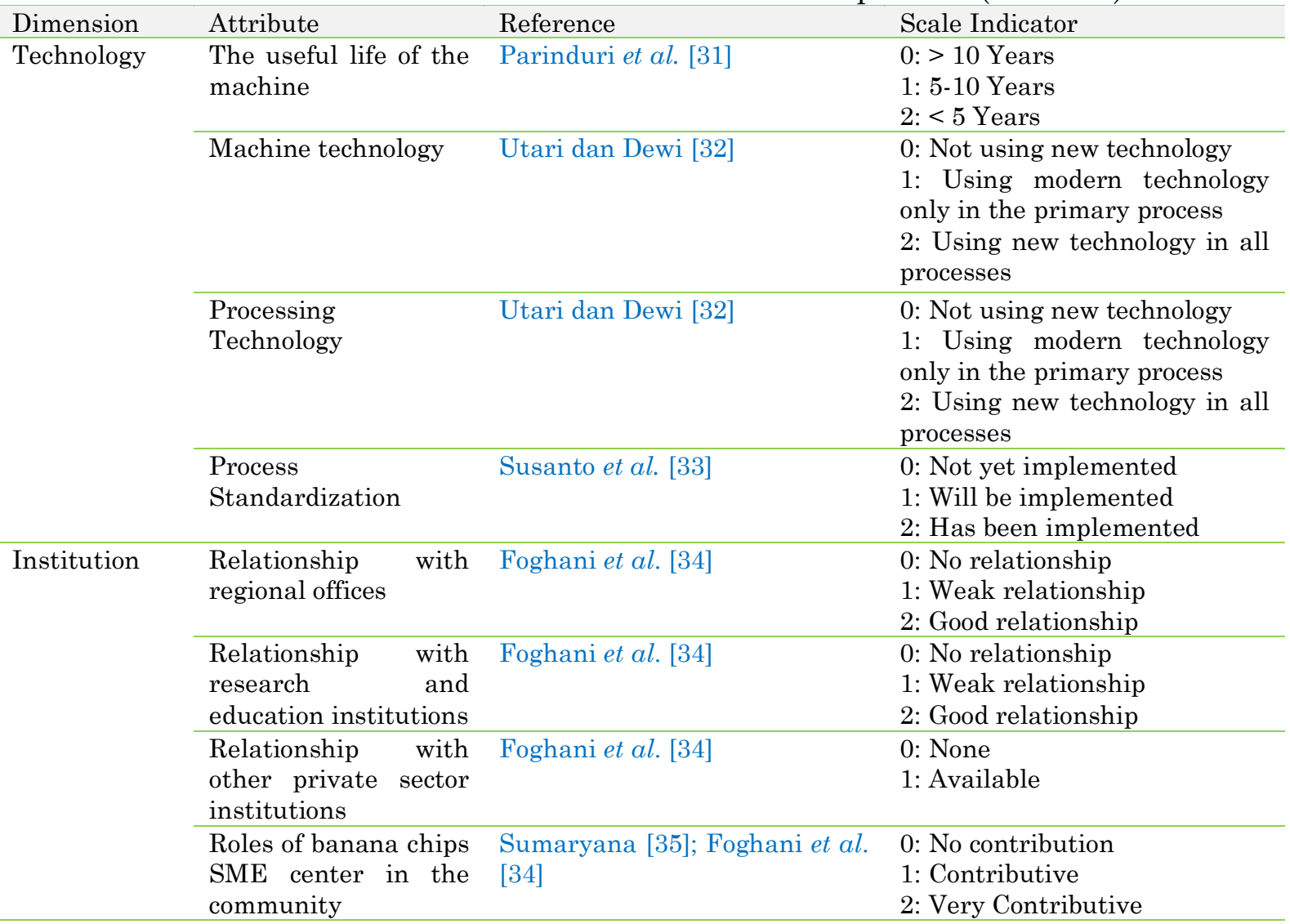

The next stage constituted giving a score of each attribute. The scores were obtained through direct interviews and questionnaires to twelve banana chip SMEs. The scales used for each indicator can be seen in Table 1 and Table 2.

\subsection{Data Analysis}

Twelve SMEs were mapped with the multidimensional scaling analysis based on the Rapid Appraisal for Fisheries (RAPFISH) approach of bad (0\%) and good (100\%) [36]. The classification of the sustainability index of the SMEs is divided into four categories: the sustainability index value $<25 \%$ shows a very poor condition of SME; the sustainability index value ranging from 25,00 to $49,99 \%$ indicates a poor condition of SME; the sustainability index value from 50 to $74,99 \%$ shows a good condition of SME, and the sustainability index value $\geq 75 \%$ demonstrates a very good condition of SME [8].

The data were validated using stress and $\mathrm{R}^{2}$ values. Monte Carlo analysis was also used for the attribute validation. It was to ensure that no error appeared in measuring the value of the sustainability index [13]. A low-stress value indicates a good fit. The best stress value category is a stress value that is smaller than $0.25(\mathrm{~S}<0.25)$. It is the ideal value to describe the condition of banana chip SMEs. Furthermore, a high-stress value indicates that it cannot represent the actual condition. The tolerance limit of this value is 0.25 [36]. The value of $\mathrm{R}^{2}$ also shows data accuracy. It also explains whether or not the addition of attributes is needed. $R^{2}$ is good if it is $>0.8$. However, if the value of $R^{2}$ is $<0.8$, the attribute addition is required [13]. 
After the data validation, leverage analysis was carried out. This analysis was used to determine the attributes that affect the sustainability index. The results of this analysis are displayed in the form of bar charts. The attributes with high values indicate a strong influence on the improvement of the sustainability index [8].

\section{Results and Discussion}

\subsection{Sustainable Index}

According to the stress and R2 values, the attributes used were appropriate as they constituted the stress value less than $0.25(\mathrm{~S}<0.25)$ and $\mathrm{R} 2>0.8$. The results of stress and R2 values are shown in Table 3. Furthermore, the Monte Carlo analysis results are presented in Table 4 (with a 95\% confidence level). The Monte Carlo value on the sustainability index constituted only a small gap. It shows that the scoring error of each attribute was relatively low. It also confirms that the analysis process was carried out firmly, and errors could be avoided.

Table 3. Stress and R2 values on the sustainability index of banana chips SMEs

\begin{tabular}{lcccc} 
Dimension & Stress value & R2 value & $\begin{array}{c}\text { Sustainability } \\
\text { index value (\%) }\end{array}$ & Category \\
\hline Ecology & 0.20 & 0.91 & 52.47 & Good \\
Social & 0.15 & 0.94 & 70 & Good \\
Economy & 0.19 & 0.93 & 56.88 & Good \\
Technology & 0.22 & 0.93 & 31.24 & Poor \\
Institution & 0.17 & 0.93 & 64.3 & Good \\
\hline
\end{tabular}

Table 4. Monte Carlo values on the sustainability index of banana chips SMEs

\begin{tabular}{lccc} 
Dimension & $\begin{array}{c}\text { Sustainability } \\
\text { index value (\%) }\end{array}$ & $\begin{array}{c}\text { Monte Carlo } \\
\text { value }\end{array}$ & Gap \\
\hline Ecology & 52.47 & 52.33 & 0.14 \\
Social & 70 & 69.95 & 0.05 \\
Economy & 56.88 & 56.54 & 0.34 \\
Technology & 31.24 & 31.73 & 0.49 \\
Institution & 64.3 & 64.71 & 0.41 \\
\hline
\end{tabular}

The sustainability index of the banana chips SMEs in Bandar Lampung is presented in Fig. 1. The figure shows the average index values of the twelve SMEs. Based on the figure, the sustainability status of the banana chips SME has divided into two categories: poor category went to the technological dimension (31.24\%); meanwhile, and good category belonged to the ecological (52.47\%), social (70\%), economic (56.88\%), and institutional dimensions (64.3\%).

Furthermore, the sustainability index values of each banana chip SME are presented in Table 5. The sustainability status of twelve banana chips SMEs is divided into poor, good, and very good categories. SMEs that belonged to poor category included SME 1, SME 2, SME 9, and SME 11. SMEs with good categories were SME 4, SME 5, SME 6, SME 7, SME 8, SME 10, and SME 12. Meanwhile, SMEs with a very good category were only SME 3.

To test the influential attributes, this study employed the root means square value of the leverage analysis. The higher the value of root means square, the higher the 
influence of the attributes on the sustainability index's status. The root means square resulted from the leverage analysis are presented in the following sections.

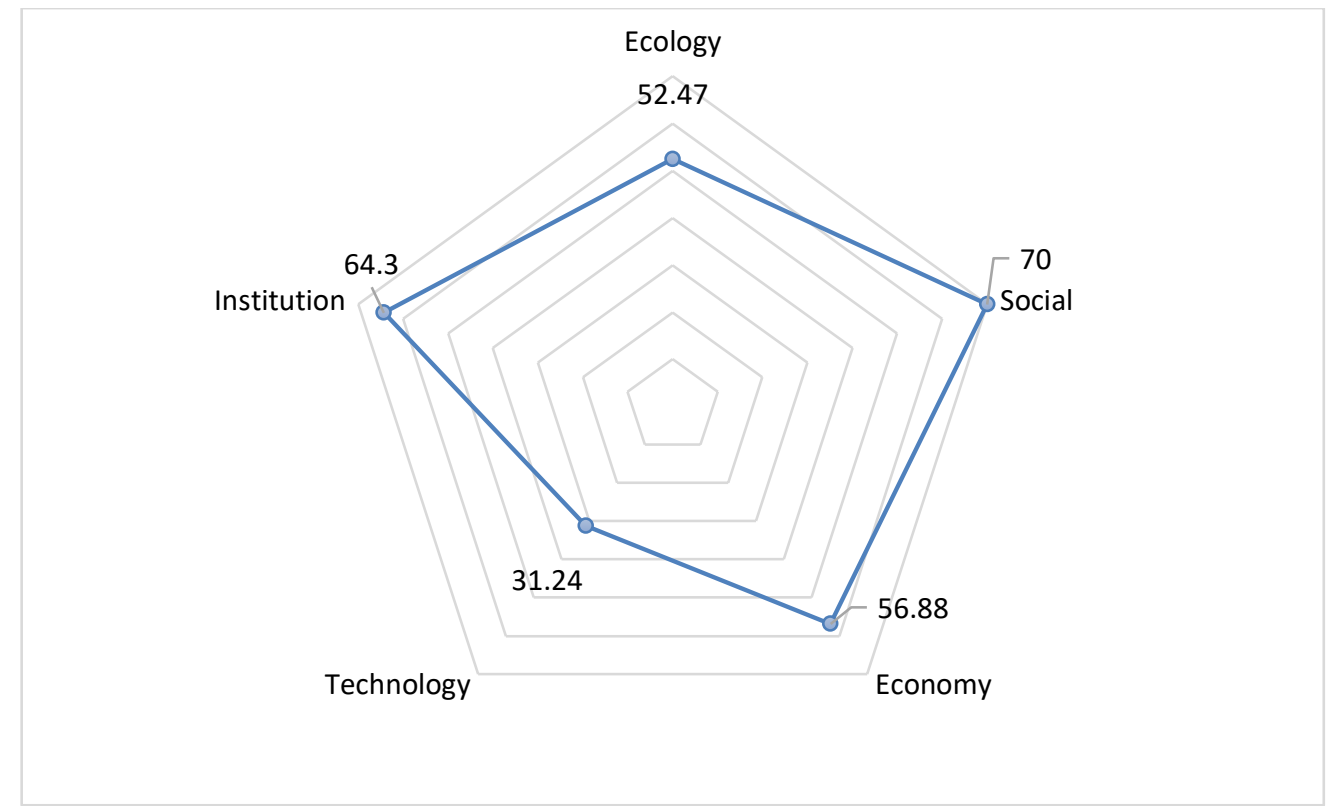

Fig. 1. Chart of the sustainability index (in percent) of banana chips SMEs

Table 5. The sustainability index values and status of banana chips SMEs

$\begin{array}{lcc}\text { Name of SME } & \text { Sustainability index value }(\%) & \text { Category } \\ \text { SME 1 } & 42,59 & \text { Poor } \\ \text { SME } 2 & 40,14 & \text { Poor } \\ \text { SME } 3 & 75,73 & \text { Very good } \\ \text { SME } 4 & 50,47 & \text { Good } \\ \text { SME } 5 & 63,56 & \text { Good } \\ \text { SME } 6 & 51,22 & \text { Good } \\ \text { SME } 7 & 66,70 & \text { Good } \\ \text { SME } 8 & 59,95 & \text { Good } \\ \text { SME } 9 & 39,95 & \text { Poor } \\ \text { SME } 10 & 58,16 & \text { Good } \\ \text { SME } 11 & 45,80 & \text { Poor } \\ \text { SME } 12 & 65,44 & \text { Good }\end{array}$

\subsection{Influence of the attributes on the sustainability index}

\subsubsection{Ecological Dimension}

Based on the leverage analysis in Fig. 2, the attribute that influenced sustainability in the ecological dimension the most was the experience of the workforce. This finding is in line with Zahro and Suyadi [22]. They argue that work experience is an essential factor for increasing work productivity. Their study shows that the experience of the workforce has a significant influence on the performance of SMEs. Meanwhile, Alhempi and Harianto [37] explain that training had a significant impact on the 
development of SMEs. It is different from the result of this study. The result of this study indicates that training had a relatively small effect on the development of SMEs.

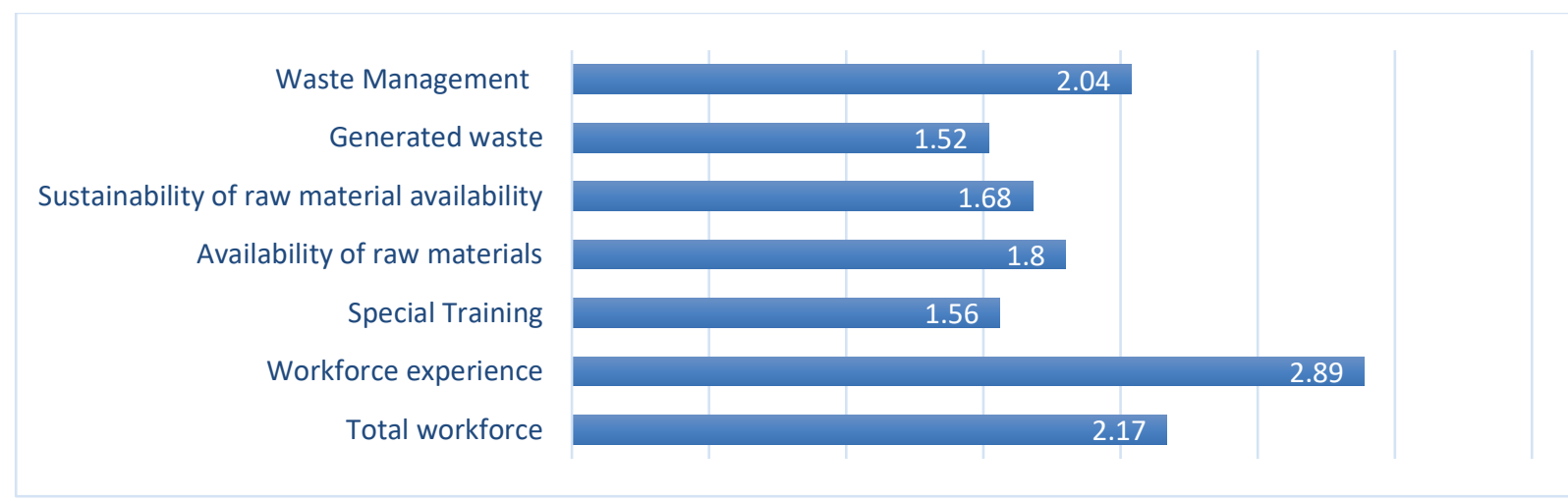

Fig. 2. Leverage graph analysis of the ecological dimension

\subsubsection{Social Dimension}

The result of the leverage analysis of the social dimension is shown in Fig. 3. The most significant attributes affecting the sustainability index were the relationship with other SMEs and the number of resellers. The relations among SMEs have already been good. However, in the present day, not all SMEs have coordinated activities to expand their market. The banana chip resellers are mostly permanent; but, the number of these resellers is relatively small. Meanwhile, the number of temporary resellers (from online) affects the sustainability index of SMEs. This result is by Hapsoro et al [38]. Consequently, SMEs are expected to innovate to keep up with the present-day technological development continuously. SMEs that have not utilized digital media have to change immediately, as Ahmad et al. [39] explain that social media can increase the brand awareness and experience of a product [39].

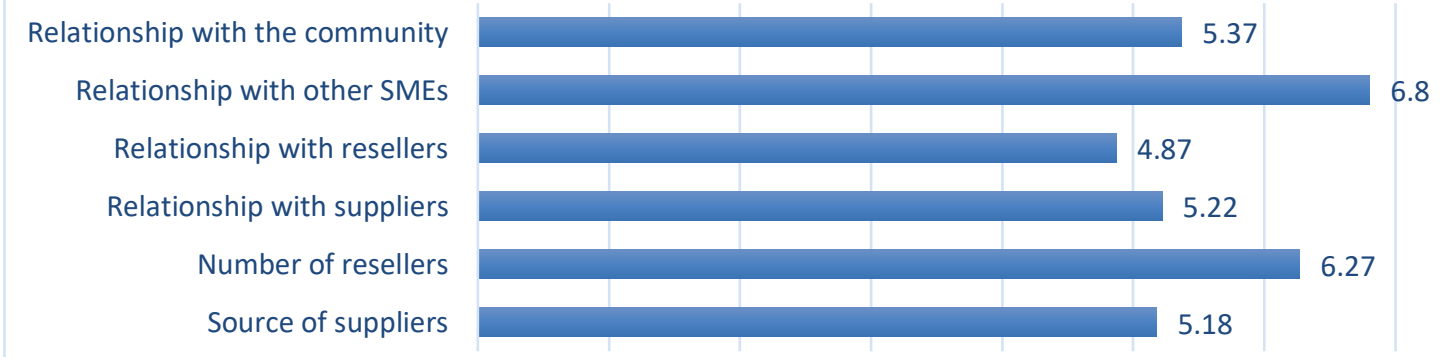

Fig. 3. Leverage graph analysis of the social dimension

\subsubsection{Economic Dimension}

Fig. 4 demonstrates that the most critical attribute for the sustainability index of the economic dimension was the marketing area. The marketing area was proportional to the number of resellers in the social dimension. It indicates that banana chips SMEs are still minimal in utilizing the technology in expanding their market share. Some SMEs nowadays have started to market their products using technology. However, some other 
manufacturers still rely on store sales. Thus, The banana chips SMEs need to keep up with the changes in the market behavior to increase the values of their sustainability index.

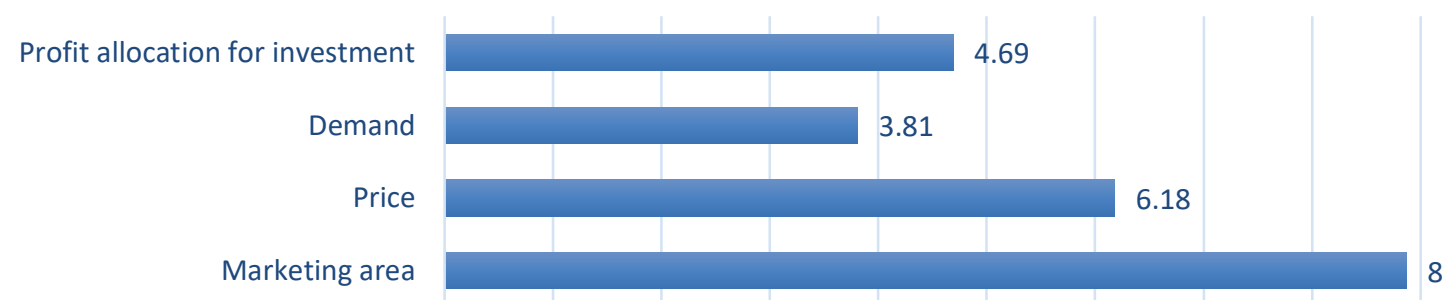

Fig. 4. Leverage graph analysis of the economic dimension

\subsubsection{Technological Dimension}

The result in Fig. 5 demonstrates that the most dominant attribute on the technological dimension is the machine's useful life. The machine has an economic age that is not profitable, although it can still be used well [31]. Therefore, banana chips SMEs need to change their machine regularly.

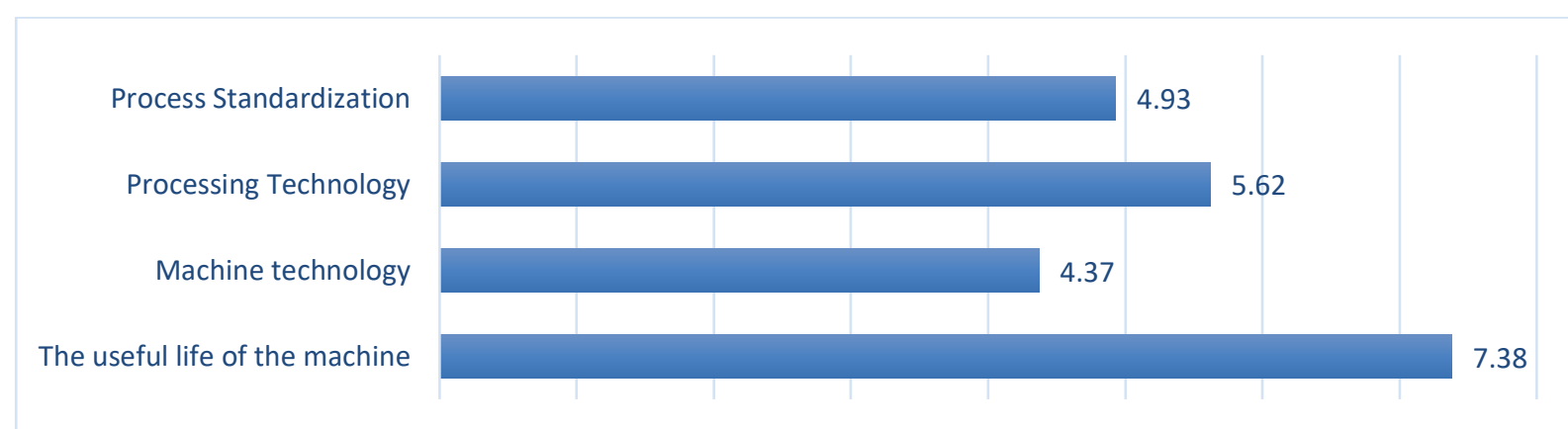

Fig. 5. Leverage graph analysis of the technological dimension

\subsubsection{Institutional Dimension}

Fig. 6 shows that the role of the banana chips SME center contributed significantly to the value of the sustainability index. The role of the SME center is mainly to help the SMEs in their marketing. Besides, the SME center and local government need to collaborate to introduce banana chip products. This research is by the study conducted by Lestari [40].

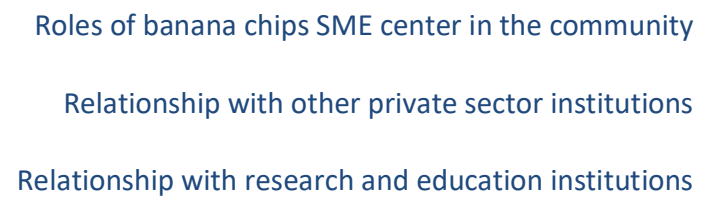

Roles of banana chips SME center in the community

Relationship with other private sector institutions

Relationship with research and education institutions

Relationship with regional offices

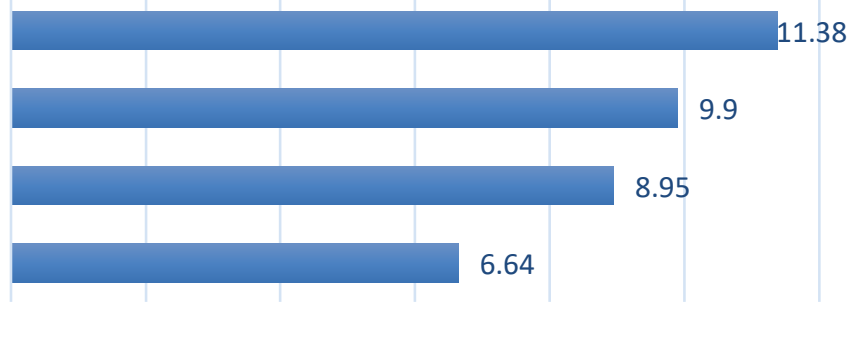

Fig. 6. Leverage graph analysis of the institutional dimension 


\section{Conclusion}

The purpose of this study is to map the sustainability index at the Banana Chips SMEs in Indonesia. This study employed five dimensions, such as ecology, social, economy, technology, and institution. The results show that the sustainability index of banana chips SMEs in Lampung Province was divided into three categories (poor, good, and very good). The five dimensions were divided into two categories: the poor category belonged to the technological dimension, and the excellent category belonged to the ecological, social, economic, and institutional dimensions. Several attributes had a significant influence on the sustainability index, such as the machine's helpful age, workforce experience and training, marketing area, number of resellers, and the role of banana chips SME center. Further research needs to be done using broader dimensions and indicators. Furthermore, further research can be developed by analyzing some appropriate strategies to improve the sustainability index.

\section{References}

[1] T. T. H. Tambunan, "Development of Micro, Small and Medium Enterprises and Their Constraints: A Story from Indonesia," 2011, vol. 13, p. 23, 2011. https://doi.org/10.22146/gamaijb.5492.

[2] D. K. Indonesia, "Kriteria Usaha Mikro, Kecil dan Menengah Menurut UU No. 20 Tahun 2008 Tentang UMKM," ed: Kementrian Koperasi dan UMKM, 2008.

[3] J. Radnor Zoe and D. Barnes, "Historical analysis of performance measurement and management in operations management," International Journal of Productivity and Performance Management, vol. 56, pp. 384-396, 2007. https://doi.org/10.1108/17410400710757105.

[4] H. Dewi, M. S. Maarif, and T. C. Sunarti, "Strategi Inovasi Peningkatan Daya Saing Usaha Mikro, Kecil, Dan Menengah Keripik Pisang Kota Bandar Lampung," $\begin{array}{llll}\text { Bogor Agricultural University } & \text { (IPB), }\end{array}$ www.repository.ipb.ac.id/handle/123456789/83322.

[5] M. Apriyani, H. Hardjomidjojo, and D. Kadarisman, "Prospek Pengembangan Usaha Keripik Pisang di Bandarlampung," MANAJEMEN IKM: Jurnal Manajemen Pengembangan Industri Kecil Menengah, vol. 9, pp. 89-95, 2014. https://doi.org/10.29244/mikm.9.1.89-95.

[6] B. Indonesia, "Profil Bisnis Usaha Mikro, Kecil dan Menengah (UMKM)," ed: Bank Indonesia, 2015. www.bi.go.id/id/umkm/penelitian/nasional/kajian/Pages/ProfilBisnis-UMKM.aspx.

[7] F. Ramdhani and H. Hardjomidjojo, "Analisis Indeks Kinerja Usaha Kecil Menengah Di Kota Bogor," Jurnal Rekayasa Dan Manajemen Agroindustri, pp. 133-152\%V 7, 2019. https://doi.org/10.24843/JRMA.2019.v07.i01.p14.

[8] T. J. Pitcher, M. E. Lam, C. Ainsworth, A. Martindale, K. Nakamura, R. I. Perry, et al., "Improvements to Rapfish: a rapid evaluation technique for fisheries integrating ecological and human dimensionsa," Journal of Fish Biology, vol. 83, pp. 865-889, 2013. https://doi.org/10.1111/jfb.12122.

[9] R. J. Stanford, B. Wiryawan, D. G. Bengen, R. Febriamansyah, and J. Haluan, "The fisheries livelihoods resilience check (FLIRES check): A tool for evaluating resilience in fisher communities," Fish and Fisheries, vol. 18, pp. 1011-1025, 2017. https://doi.org/10.1111/faf.12220. 
[10] M. E. Lam, "The Ethics and Sustainability of Capture Fisheries and Aquaculture," Journal of Agricultural and Environmental Ethics, vol. 29, pp. 35-65, 2016. https://doi.org/10.1007/s10806-015-9587-2.

[11] H. Hardjomidjojo and S. Raharja, "Pengukuran Indeks Keberlanjutan Industri Gula," MANAJEMEN IKM: Jurnal Manajemen Pengembangan Industri Kecil Menengah, vol. 11, pp. 89-96, 2016. https://doi.org/10.29244/mikm.11.1.89-96.

[12] R. Nurmalina, "Analisis Indeks dan Status Keberlanjutan Sistem Ketersediaan Beras di Beberapa Wilayah Indonesia," 2016, vol. 26, p. 33, 2016. https://doi.org/10.21082/jae.v26n1.2008.47-79.

[13] Marimin, M. A. Darmawan, R. P. Widhiarti, and Y. K. Teniwut, "Green productivity improvement and sustainability assessment of the motorcycle tire production process: A case study," Journal of Cleaner Production, vol. 191, pp. 273282, 2018. https://doi.org/10.1016/j.jclepro.2018.04.228.

[14] A. Abdullah, H. M. Ali, and J. A. Syamsu, "Status Keberlanjutan Adopsi Teknologi Pengolahan Limbah Ternak sebagai Pupuk Organik," 2015, p. 10, 2015. https://doi.org/10.29313/mimbar.v31i1.849.

[15] M. Hidayanto, S. S., S. Yahya, and L. I. Amien, "Analisis Keberlanjutan Perkebunan Kakao Rakyat di Kawasan Perbatasan Pulau Sebatik, Kabupaten Nunukan, Provinsi Kalimantan Timur," 2016, vol. 27, p. 17, 2016. https://doi.org/10.21082/jae.v27n2.2009.213-229.

[16] E. Edwarsyah, R. Safrina, and R. Safrina, "Indek dan Status Keberlanjutan Pulau Kecil Terluar: Studi Kasus Pesisir Pulo Raya Aceh Jaya," Tropical Fisheries Management Journal, vol. 1, pp. 2018. https://doi.org/10.29244/jppt.v1i1.20153.

[17] R. Marota, M. Marimin, and H. Sasongko, "Perancangan Dan Penerapan Material Flow Cost Accounting Untuk Peningkatan Keberlanjutan Perusahaan PT XYZ," 2015, vol. 12, 2015. https://doi.org/10.17358/jma.12.2.92.

[18] P. Papilo, Marimin, E. Hambali, and I. S. Sitanggang, "Sustainability index assessment of palm oil-based bioenergy in Indonesia," Journal of Cleaner $\begin{array}{lllll}\text { Production, } & \text { vol. } & 196, & \text { pp. } & 808-820,\end{array}$ https://doi.org/10.1016/j.jclepro.2018.06.072.

[19] T. J. Pitcher and D. Preikshot, "rapfish: a rapid appraisal technique to evaluate the sustainability status of fisheries," Fisheries Research, vol. 49, pp. 255-270, 2001. https://doi.org/10.1016/S0165-7836(00)00205-8.

[20] K. Sonny, M. A. Iqbal, K. Taryono, and H. Tjahjo Tri, "Pengembangan Teknik Rapid Appraisal For Fisheries (RAPFISH) untuk Penentuan Indikator Kinerja Perikanan Tangkap Berkelanjutan di Indonesia," Buletin Ekonomi Perikanan, vol. 6, 2005. www.journal.ipb.ac.id/index.php/bulekokan/article/view/2547.

[21] I. D. K. R. Ardiana, I. A. Brahmayanti, and S. Subaedi, "Kompetensi SDM UKM dan Pengaruhnya Terhadap Kinerja UKM di Surabaya," 2010, vol. 12, p. 14, 2010. www.jurnalmanajemen.petra.ac.id/index.php/man/article/view/17988.

[22] H. M. Zahro, B. Suyadi, and S. Djaja, "Pengalaman Kerja Dan Curahan Jam Kerja Terhadap Kinerja Karyawan (Studi Kasus Pada Home Industry Tas Pita Plastik Bapak Almunir Di Desa Setail Kecamatan Genteng Kabupaten Banyuwangi Tahun 2017)," Jurnal Ilmiah Ilmu Pendidikan, vol.12, pp. 8-14, 2018. https://doi.org/10.19184/jpe.v12i1.6464.

[23] R. Hidayati, M. Muslikh, and N. Nazwirman, "Pelatihan dalam Upaya Meningkatkan Daya Saing Produk UKM Di Kampung Wisata Bisnis Tegalwaru 
Bogor," Abdimas Pedagogi: Jurnal Ilmiah Pengabdian kepada Masyarakat, vol. 2, pp. 15-20, 2018. www.journal2.um.ac.id/index.php/pedagogi/article/view/3325.

[24] D. Wuryandani and H. Meilani, "Peranan Kebijakan Pemerintah Daerah dalam Pengembangan Usaha Mikro, Kecil, dan Menengah di Provinsi Daerah Istimewa Yogyakarta," Jurnal Ekonomi Dan Kebijakan Publik, vol. 4, pp. 103-115, 2013. www.jurnal.dpr.go.id/index.php/ekp/article/view/71.

[25] A. S. Cahyana, C. Subakti, and B. A. Noer, "Pengembangan Model Kinerja Lingkungan Bagi Industri Kecil dan Menengah (IKM) dengan Pendekatan Structural Equation Modeling (SEM)," 2012. www.hdl.handle.net/11617/3921.

[26] V. Y. Erviana, I. Suwartini, and A. Mudayana, "Pengolahan Limbah Minyak Jelantah dan Kulit Pisang Menjadi Sabun," Jurnal SOLMA, vol. 7, pp. 144-152, 2018. https://doi.org/10.29405/solma.v7i2.2003.

[27] R. Rostamzadeh and S. Sofian, "Prioritizing effective 7Ms to improve production systems performance using fuzzy AHP and fuzzy TOPSIS (case study)," Expert Systems with Applications, vol. 38, pp. 5166-5177, 2011. https://doi.org/10.1016/j.eswa.2010.10.045.

[28] S. Subroto, I. M. Hapsari, and Y. P. Astutie, "Analisis Faktor-Faktor Yang Mempengaruhi Kinerja Usaha Mikro Kecil Dan Menengah (UMKM) Kabupaten Brebes," Prosiding SNaPP: Sosial, Ekonomi dan Humaniora, vol. 6, pp. 337-344, 2016. www.proceeding.unisba.ac.id/index.php/sosial/article/view/202.

[29] A. K. Anam and M. Setyawan, "Strategi Pengembangan Produk Unggulan Daerah Berbasis Klaster Pada Sentra Kawasan Industri Rotan Di Kabupaten Jepara," MANDAR: Management Development and Applied Research Journal, vol. 1, pp. 18, 2019. www.ojs.unsulbar.ac.id/index.php/mandar/article/view/368.

[30] S. Nurseto, "Pengaruh Saluran Distribusi Dan Promosi Terhadap Kinerja Pemasaran (Studi Kasus Pada UKM Furniture Kota Semarang)," 2017, p. 6, 2017. https://doi.org/10.14710/jab.v5i2.16237.

[31] L. Parinduri, S. R. Sibuea, and W. Suryadi, "Analisa Umur Ekonomis Mesin Perebusan Untuk Perencanaan Replacement (Studi Kasus Di PT. PN IV Kebun Adolina Perbaungan)," Buletin Utama Teknik, vol. 14, pp. 6-12, 2018. www.jurnal.uisu.ac.id/index.php/but/article/view/794.

[32] T. Utari and N. P. M. Dewi, "Pengaruh Modal, Tingkat Pendidikan dan Teknologi Terhadap Pendapatan Usaha Mikro Kecil dan Menengah (UMKM) Di Kawasan Imam Bonjol Denpasar Barat," E-Jurnal Ekonomi Pembangunan Universitas Udayana, 2014. www.ojs.unud.ac.id/index.php/eep/article/view/9916.

[33] D. A. Susanto, F. Isharyadi, and N. Aliyah, "Faktor-Faktor Yang Memengaruhi Usaha Kecil Menengah Dalam Menerapkan Standar Secara Konsisten," 2018, vol. 18, p. 10, 2018. https://doi.org/10.31153/js.v18i2.705.

[34] S. Foghani, B. Mahadi, and R. Omar, "Promoting Clusters and Networks for Small and Medium Enterprises to Economic Development in the Globalization Era," SAGE Open, vol. 7, p. 2158244017697152, 2017. https://doi.org/10.1177/2158244017697152.

[35] F. D. Sumaryana, "Pengembangan Klaster UMKM Dalam Upaya Peningkatan Daya Saing Usaha," 2018, vol. 8, p. 11, 2018. https://doi.org/10.15575/jp.v8i1.2771.

[36] A. Fauzi and S. Anna, "Evaluasi status keberlanjutan pembangunan perikanan: aplikasi pendekatan Rapfish," Formulir Berlangganan Jurnal Pesisir dan Lautan, vol. 43, 2002. www.crc.uri.edu/download/JournalPLVol4No3-O.pdf\#page=46. 
[37] R. R. Alhempi and W. Harianto, Pengaruh Pelatihan dan Pembinaan Terhadap Pengembangan Usaha Kecil Pada Program Kemitraan Bina Lingkungan: Faculty of Business and Economics, Trisakti University, 2013. www.trijurnal.lemlit.trisakti.ac.id/mrbm/article/view/1122.

[38] B. B. Hapsoro, P. Palupiningdyah, and A. Slamet, "Peran Digital Marketing sebagai Upaya Peningkatan Omset Penjualan Bagi Klaster UMKM di Kota Semarang," Jurnal Abdimas, vol. 23, pp. 117-120, 2019. www.journal.unnes.ac.id/nju/index.php/abdimas/article/view/17880.

[39] N. S. Ahmad, S. A. Bakar, and R. Musa, "Exploring the Roles of Social Media Content Marketing (SMCM) Towards Return on Investment (ROI): A Conceptual Paper," 2017.

[40] E. P. Lestari, "Penguatan Ekonomi Industri Kecil Dan Menengah Melalui Platform Klaster Industri," Jurnal Organisasi Dan Manajemen, pp. 146-157\%V 6, 2010. www.ilp.ut.ac.id/index.php/JOM/article/view/289. 